\title{
70. Teknik çeviri eğitiminde (öz)düşünümsel performanslar: Çeviri yorum yazıları
}

\section{Zeynep SÜTER GÖRGÜLER ${ }^{1}$}

\begin{abstract}
APA: Süter Görgüler, Z. (2021). Teknik çeviri eğitiminde (öz)düşünümsel performanslar: Çeviri yorum yazları. RumeliDE Dil ve Edebiyat Araştırmaları Dergisi, (23), 1085-1099. DOI: $10.29000 /$ rumelide.950017.
\end{abstract}

\section{$\ddot{O} \mathbf{z}$}

Küreselleşme hareketiyle birlikte çeviri eylemi ve çevirmen kimliği dijital ağlarda yeniden üretilmektedir. Ağlarda biçimlenen yeni çeviri pratikleri ve çevirmen kimlikleri, çeviri eğitiminde başvurulan yöntemlerin de bu doğrultuda değişip dönüşmesini zorunlu kılmaktadır. Çeviri eğitiminde, öğrencilerin (öz)düşünümsel performanslarını konu alan çalışmalar önem kazanmaktadır (Garcīa Álvarez, 2007; Kelly, 2005; Presas, 2012; Shih, 2018). Bu noktadan hareketle, ilgili araştırma çalışmasında, erek metinlere eklemlenen ve düşünümsel rapor niteliği taşıyan çeviri yorum yazılarının önemi üzerinde durulmaktadır. Bu çerçevede, Yıldız Teknik Üniversitesi Batı Dilleri ve Edebiyatları Bölümü Fransızca Mütercim ve Tercümanlık Bölümü’nde 2020-2021 eğitim-öğretim yılı güz döneminde yürütülen MTF 2141 Teknik Çeviri 1 dersinde yapılan final sınavı mercek altına alınmaktadır. İlgili sınava katılan öğrencilerin kaleme aldıkları çevirmen ön sözü olarak adlandırılan çeviri yorum yazıları, (öz)düşünümsel yaklaşımlar (Bourdieu ve Wacquant, 2007) ve ilişkili diğer kavramlar ve yöntemler ışı̆̆ında çözümlenmektedir. Saha çalışması kapsamında, beş öğrencinin oluşturduğu çeviri yorum yazıları ele alınmaktadır. Anlamlı öğrenme, keşfederek öğrenme, öz kontrol, öz yönetim, etik sorumluluk, bilişsel düşünme pratikleri, deklaratif ve prosedürel bilgi gibi kavramlar, araştırmanın kuramsal ve yöntemsel dayanaklarını oluşturmaktadır. İlgili öğrencilerin, ürettikleri çeviri yorum yazıları etrafında sergiledikleri (öz)düşünümsel performanslarında, sözü edilen bu kavramların izleri sürülmektedir. Ayrıca, bu yönde oluşturulan yansıtıcı rapor çalışmalarının, yeni medya çevirmeni konumundaki öğrencilerin (öz)düşünümsel farkındalıklarını geliştiriyor olmasının altı çizilmektedir.

Anahtar kelimeler: Teknik çeviri eğitimi, (öz)düşünümsellik, çeviri yorum yazıları, çevirmen, yeni medya

\section{Self(reflexive) performances in technical translation training: Translation commentaries}

\begin{abstract}
With the globalization movement, translation pratice and translator identity are reproduced in digital networks. New translation practices and translator identities shaped in networks require the methods used in translation training to change and transform accordingly. Studies on (self)reflexive performances gain importance in translation training (Garcia Álvarez, 2007; Kelly, 2005; Presas, 2012; Shih, 2018). From this point of view, the importance of translation commentary, which is attached to the target texts and qualifies as reflective reports, is emphasized in the relevant research study. In this context, the final exam held in the MTF 2141 Technical Translation 1 course
\end{abstract}

Arş. Gör. Dr., Yıldız Teknik Üniversitesi, Fen-Edebiyat Fakültesi, Batı Dilleri ve Edebiyatları Bölümü, Fransızca Mütercim ve Tercümanlı ABD (İstanbul, Türkiye), zeynepsuter@gmail.com, ORCID ID: oooo-0001-6538-4840 [Araştırma makalesi, Makale kayıt tarihi: 26.04.2021-kabul tarihi: 20.06.2021; DOI: 10.2900o/rumelide.950017]

Adres Address

RumeliDE Dil ve Edebiyat Araşttrmaları Dergisi $\quad$ RumeliDE Journal of Language and Literature Studies Osmanağa Mahallesi, Mürver CCiçeği Sokak, No:14/8 Osmanağa Mahallesi, Mürver Çiçeği Sokak, No:14/8

Kadıköy - İSTANBUL / TÜRKIYE 34714 Kadıköy - ISTANBUL / TURKEY 34714 e-posta: editor@rumelide.com

e-mail: editor@rumelide.com,

tel: +90 $5057958124,+90216773$ o 616 phone: +90 505 7958124, +90 216773 o 616 
conducted in the fall semester of the 2020-2021 academic year at Ylldı Technical University, Department of Western Languages and Literatures, French Translation and Interpretation Department is being scrutinized. The translation commentaries, called translator prefaces, written by the students participating in the relevant exam are analyzed in the light of (self)reflexive approaches (Bourdieu \& Wacquant, 2007) and other related concepts and methods. Within the scope of the field study, translation commentaries written by five students are handled. Concepts such as meaningful learning, learning by discovery, self-control, self-management, ethical responsibility, cognitive thinking practices, declarative and procedural knowledge constitute the theoretical and methodological basis of the research. These concepts are traced within the (self)reflexive performances of the relevant students around the translation commentaries they produce. In addition, it is underlined that the reflective report created in this direction improve the (self)reflexive awareness of students who are new media translators.

Keywords: Technical translation training, self(reflexivity), translation commentaries, translator, new media

\section{Giriş}

Küreselleşme süreciyle birlikte yeni medya ve iletişim teknolojilerinin çeşitlenerek gelişmesi, çeviri eylemine ve çevirmene duyulan ihtiyacı her geçen gün artırmaktadır. Küreselleşen üretim ve tüketim koşulları, çeviri pratiğini ve çevirmen kimliğini yeniden inşa etmektedir. Bu kapsamda, çeviri pratiği yeni kavramlar etrafında tanımlanırken, çevirmenin de farklı becerilerle ve yeteneklerle donatılması gündeme gelmektedir. Çevirmeni "çoklu medya ortamlarında çok dilli iletişimi sağlayan mühendis" olarak nitelendiren Daniel Gouadec, çevirmenin çok kimlikli doğasına dikkat çekmektedir (2002: 59)². Gouadec'e göre, yeni medya ortamlarında, çevirmenin, "bilgi yönetme, terim yönetme, kalite kontrol yapma, teknik metin yazma, belge yönetme" gibi becerilere ve yetilere sahip olması gerekmektedir (2002: 59). Bu doğrultuda öne çıkan beklentiler, çevirmeninin, yeni bilgi ve deneyim alanları çerçevesinde değişip, dönüşmesini zorunlu kılmaktadır. Bundan böyle, çevirmenden, "tedarik zincirini yönetebilmesi, dillerarası ve kültürlerarası iletişim kurabilmesi, stratejik, yöntemsel ve tematik bilgi edinebilmesi, yeni medya ve iletişim teknolojilerini kullanabilmesi ve son olarak da hem bireysel anlamda, hem de bireylerarası, proje merkezli çalışabilme becerileri geliştirmesi” istenmektedir (EMT, 2017). Çeviri eğitimi programlarının da dönüşen küresel pazar koşulları göz önünde bulundurularak yeniden inşa edilmesi gündemde yer almaktadır.

Araştırma kapsamında, çevirmenin, çeviri sürecinde uyguladığı stratejileri ve kararları betimleyen çeviri yorum yazılarının önemi üzerinde durulmaktadır. Bu çerçevede, Yıldız Teknik Üniversitesi Batı Dilleri ve Edebiyatları Bölümü Fransızca Mütercim ve Tercümanlık Bölümü’nde 2020-2021 eğitimöğretim yılı güz döneminde yürütülen $M T F 2141$ Teknik Çeviri 1 dersinde yapılan final sınavı üzerine odaklanılmaktadır. İlgili sınava katılan öğrencilerin sergiledikleri (öz)düşünümsel performansları, kaleme aldıkları çeviri yorum yazıları etrafında çözümlenmektedir. Sınavda, ilgili öğrencilerden "Gig Economy: des travailleurs du clic à l'économie des petits boulots” başlıklı Fransızca metni Türkçeye çevirmeleri istenmiştir. İlgili metin, esnek ekonomi olarak ifade edilen gig ekonomisinin nitelikleri üzerine yoğunlaşmaktadır. Kaynak metinde disiplinlerarası niteliklere sahip terimlere yer verilmektedir. Öğrencilerin, terimlerin çevirisine yönelik benimsedikleri stratejiler ve aldıkları kararlar, çeviri yorum yazılarının değerlendirilmesinde etkili olmuştur.

2 Aksi belirtilmediği taktirde, metin içindeki tüm çeviriler çalışmanın yazarı tarafından yapılmıştır. Adres | Address

RumeliDE Dil ve Edebiyat Araşttrmalar Dergisi $\quad$ RumeliDE Journal of Language and Literature Studies Osmanağa Mahallesi, Mürver Çiçeği Sokak, No:14/8 Osmanağa Mahallesi, Mürver Çiçeği Sokak, No:14/8 Kadıköy - İSTANBUL / TÜRKIYE 34714 Kadıköy - ISTANBUL / TURKEY 34714 e-posta: editor@rumelide.com

e-mail: editor@rumelide.com,

tel: +90 505 7958124, +90 2167730616 phone: +90 505 7958124, +90 2167730616 
Teknik çeviri alanı, "teknik, teknolojik ve bilimsel içerikli metinlerin çevirisine" odaklanmaktadır (Durieux, 1988: 23). Teknik metin çevirmeninden, çevirisini üretirken içerisinde bulunduğu koşulları göz önünde bulundurması beklenmektedir. Bir başka deyişle, teknik metin çevirmenin ya da bu araştırma çerçevesinde öğrencinin, üreteceği çeviri metin ile nasıl bir ilişki kuracağı bu süreçte benimseyeceği özdüşünümsel farkındalığı ortaya koymaktadır. Bu açıdan bakıldığında, önemli olan mesele, araştırmacının, "zihninde bu ilişkiyi nasıl soyutladığı, nasıl kurguladığı, neleri dışlayıp neleri içerdiği, kendi 'ben' ini sorgulaması ve konusu ile arasında nasıl bir boşluk bıraktığının farkında olması" ile ilişkilidir (Binark, 2005: 187). Bu noktada, öğrencinin yarattığı çevirmen kimliğine ve ürettiği çeviri pratiklerine yönelik eleştirel ve sorgulayıcı bir bakış açısı geliştirmesi, “(öz)düşünümsellik” kavramı etrafında ele alınabilmektedir.

Araştırma konusuna geri dönülecek olunursa, ilgili final sınavı kapsamında beş öğrencinin oluşturduğu çeviri yorum yazılarında yanıt aranan sorular şunlardır: ilgili öğrencilerin kaleme aldıkları çeviri yorum yazılarıyla, anlamlı öğrenme ve keşfederek öğrenme yöntemleri arasında ilişkisellik kurulabilmekte midir? Çeviri yorum yazılarının, ilgili öğrencilerin öz değerlendirme ve öz kontrol gibi becerilerini geliştirdiğinden söz edilebilmekte midir? Bununla birlikte, bu yöndeki çalışmaların, öğrencilerin üst dilsel ve bilişsel düşünme pratiklerini ve teknik çeviri sürecindeki etik kavrayışlarını desteklediği belirtilebilmekte midir? Son olarak, çeviri yorum yazıları, öğrencilerin inşa ettikleri çevirmen kimliklerinin güçlenmesinde etkili midir?

Bu sorulara verilecek yanıtlar ışı̆̆ında, ilgili final sınavında, öğrencilerin kaleme aldıkları çeviri yorum yazıları ile (öz)düşünümsel performans sergileme nitelikleri ve biçimleri arasındaki ilişkiselliğin ortaya konması amaçlanmaktadır.

\section{Kavramsal ve yöntemsel çerçeve: (Öz)düşünümsel farkındalık ve çeviri yorum yazıları}

\section{1. (Öz)düşünümsellik hakkında genel bilgi}

Düşünümsellik (fr. "réflexion”), "hem bir şey üzerine düşünme, hem de yansıtma" anlamı taşımaktadır (Wacquant, 2012: 11). Pierre Bourdieu'ye göre, düşünümsellik, "bireysel olandaki toplumsalı, mahremin altında gizlenen gayri şahsiyi, özelin en derine gömülmüş evrenseli keşfettiren” bir yaklaşım biçimidir (Bourdieu ve Wacquant (Çev. Ökten), 2007: 40). Bu çerçevede, "katılımcı nesneleştirme" olgusuna dayanan düşünümsel çözümlemede, araştırmacı, araştırma nesnesini ve onun üretildiği ve tüketildiği toplumsal dünyayı nesneleştirmeye çabalarken, kendi kimliğini de bu sürece dahil etmektedir. Araştırmacı, bu süreçte, toplumsal ve akademik alandaki konumunu nesnelleştirmektedir (Bourdieu ve Wacquant (Çev. Ökten), 2007: 53). Kısacası, düşünümsellik, "araştırmacının gerçekleştirdiği pratikler arasında ilişkisellik kurarak düşünmesi ve eylemesidir" (Wacquant (Çev. Ökten), 2012: 38). Görüldüğü üzere, araştırmacıdan kendi bilimsel kimliğini özdüşünümsel bir nesneleştirme sürecine tabi tutması beklenmektedir. Araştırmacının onu çevreleyen toplumsal, siyasal, kültürel, ekonomik ve tarihi olgulara önyargısız bakabilmesi ve sözü edilen değerler sistemiyle mücadele etmesi ve yüzleşmesi bu süreçte oldukça önemlidir.

Yukarıda Gouadec'in belirttiği gibi, günümüzde teknik çeviriyi bir yeni medya pratiği olarak ele almak mümkündür. Yeni medya ortamlarında yürütülen araştırmalarda, "özdüşünümsellik" hususu merkezde yer almaktadır. Bir yeni medya araştırması hangi pratik üzerine yoğunlaşırsa yoğunlaşsın, "araştırmacıdan samimi olması, kavramsal ve kuramsal yaklaşımını tutarlı bir şekilde çatması

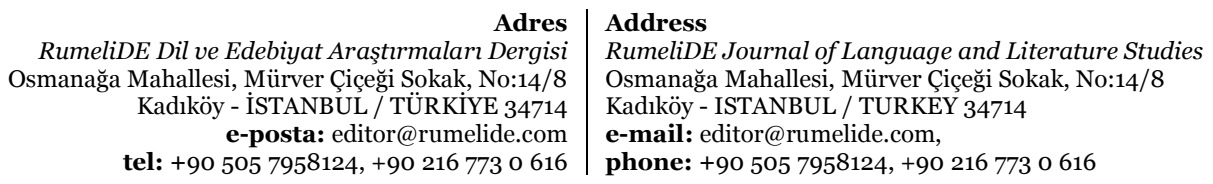


gerektiğini bilmesi, ve sahaya indiği zaman topluma ve bireye dokunduğunu unutmaması" beklenmektedir (Binark, 2014: 29). Bu kapsamda, araştırmacı, özdüşünümsel tavrıly birlikte, yeni medya temelli araştırma etkinliği içinde, "kendi derdi, sorunları ve kavram seti, olay ve olgulara bakış açısı ile yüzleşme, sorgulama ve hesaplaşma içeren bir yolculuğa çıkmaktadır" (Binark, 2014: 29). Araştırmacının, "benimsediği yöntem ve teknikleri nasıl yaşama geçirdiğini anlatması, uygulama aşamasında yaşadığı sorunları ve bulduğu çözüm yollarını ya da daha genel bir ifadeyle deneyimlerini paylaşması, araştırmacının yerine getirmesi gereken etik bir sorumluluktur" (Binark, 2014: 29). Yeni medya araştırmalarında, araştırmacı, özdüşünümsel tavrıyla birlikte, "toplumda kendini konumlandırmakta, topluma ve araştırma alanına hangi açıdan, hangi mesafeden bakacağına karar vermektedir" (Binark, 2014: 25). Özdüşünümsellik, "yeni medya araştırmacısına, araştırma sürecinde yeni yolların, bu yolların kesişme ya da tamamen farklılaşma süreçlerinin var olabileceğini göstermektedir" (Tunç, 2014: 178).

\section{2. Çeviri yorum yazıları hakkında genel bilgi}

Sorun çözmeye dayalı öğrenme yöntemi çerçevesinde, Chris Shei (2005), çeviri yorum yazılarını bilinç yükseltme çalışması ve değerlendirme ölçütü olarak ele almaktadır. Bu noktadan hareketle, yazar, çeviri yorumlarını, "çeviri metne ve görevine eşlik eden, öğrencinin metin ve bağlam analizi yaptığı, sorun çözme süreçlerini açlkladığı bir kompozisyon ödevi” olarak tanımlanmaktadır (2005: 315). Schäffner'a (2001) göre, çeviri yorum yazılarında, çeviri sorunlarına odaklanmak ve bu doğrultuda başvurulan çeviri stratejilerini tartışmaya açmak hedeflenmektedir. Aynı zamanda, çeviri yorum yazıları, çevirmeni "eleştirel" düşünceye teşvik etmektedir. Bu doğrultuda yapılan çeviri yorum çalışmaları, "çevirmeni bilinçli kararlar alması konusunda yönlendirmekte, çevirmenin bu kararlara yönelik yorum yapmasını sağlamakta ve gerektiği yerde çevirmene bu kararları savunma firsatı vermektedir" (2001: 3). Wang Xiang, öğrenciler tarafından üretilen yorum yazılarını "kendini izleme" yöntemi çerçevesinde değerlendirmektedir. Çeviri yorum yazılarında, öğrenci "üst bilişsel ve üst dilsel düşünme” pratikleri geliştirmektedir (2004: 238). Anabel Galán-Mañas ve Amparo Hurtado Albir, çeviri yorum yazısı oluşturma eylemini, "öğrencilerin bir metni çevirirken karşılaştıkları sorunları ifade ettikleri, bunları çözmek için izledikleri süreci açıkladıkları, başvurdukları kaynakları dile getirdikleri bir görev" olarak ele almaktadırlar (2015: 71). Aynı zamanda, ilgili yazarlar, çeviri yorum yazılarını, çeviri metne eklenmiş “yansıtııı bir rapor” olarak değerlendirmektedirler (2015: 71).

Çeviri eğitiminde, öğrenci merkezli ve süreç temelli yaklaşımların önem kazanmasıyla birlikte, çeviri yorum yazılarına ölçme-değerlendirme yöntemi olarak daha sık başvurulmaktadır (Kiraly 2000, 2003). Dorothy Kelly'ye göre, çeviri metin üzerine yapılan yorumlar, "çeviri portföylerinin önemli bir bileşeni” olarak varlığını sürdürmektedir (2005: 139). Çeviri yorum yazılarını, çeviri eğitiminde başvurulan bir ölçme-değerlendirme yöntemi olarak kavramsallaştıran Claire Yi-yi Shih, çeviri yorum çalışmaları odağında, "bilgi, beceri, kuram ve uygulama" alanları arasında kurulan sinerjiye dikkat çekmektedir (2018: 291). Çeviri metne yönelik öğrencilerin oluşturdukları çeviri yorum yazılarında, öğrenciler "düşünümsel” bir süreci deneyimleyerek, geleceğe yönelik çalışmalarında uygulayacakları farklı çeviri pratiklerini geliştirmektedirler. Böylelikle öğrenciler benimsedikleri çeviri kararları ve stratejileri arkasında yer alan gerekçeleri, "yüksek sesle ifade etme" firsatı yakalamaktadırlar (Shih, 2018: 293). Tutarlı bir şekilde kaleme alınmış olan çeviri yorum metninde, öğrenci atıfta bulunduğu kuramsal yaklaşımları içselleştirdiğini ve bunları çeviri sürecinde etkin bir şekilde uygulayabildiğini ortaya koymaktadır. Bununla birlikte, öğrenciden uyguladığı çeviri stratejilerine ilişkin “özdüşünümsel” bir konumdan hareketle, kendi üretim sürecini gözlemleyebilmesi için beceriler geliştirmesi de beklenmektedir (Shih, 2018: 302).

RumeliDE Dil ve Edebiyat Araşttrmaları Dergisi Osmanağa Mahallesi, Mürver Ciçeği Sokak, No:14/8 Kadıköy - İSTANBUL / TÜRKIYE 34714 e-posta: editor@rumelide.com tel: +90 $5057958124,+902167730616$
Address

RumeliDE Journal of Language and Literature Studies

Osmanağa Mahallesi, Mürver Çiçeği Sokak, No:14/8

Kadıköy - ISTANBUL / TURKEY 34714

e-mail: editor@rumelide.com,

phone: +90 5057958124 , +90 2167730616 
Çeviri yorum yazılarının, tutarlı bir tartışma ortamı üzerine temellendirilmesine ve akademik bir üslupla ve bilimsel akıl yürütme yöntemiyle oluşturulması gerektiğine vurgu yapan Shih (2018), çeviri yorum yazılarının niteliğine ilişkin iki unsura dikkat çekmektedir. Bir yandan, çeviri yorum yazıları, öğrencilerin kararlarını yansıtan "düşünümsel bir rapor" üretme eylemi olarak anlam kazanmaktadır. Diğer taraftan ise, yazar bu yönde üretilen içeriklerin "akademik deneme çalışması" olarak değerlendirilmesini gündeme taşımaktadır. Bir başka deyişle, çeviri yorum yazıları, öğrencilerin çevirdikleri metinlerden hareketle oluşturdukları ve bu süreçte öğrencilerin eleştirel düşünce üretme becerilerini tetikleyen ve destekleyen "melez" bir kavram olarak anlam kazanmaktadır (Shih, 2018: 308). Çeviri metne eklemlenen bu yöndeki yorum çalışmalarıyla, öğrencinin "yöntemsel ve kuramsal bilgisi, sorun çözme kapasitesi, art alan araştırma becerisi ve bunları yansitabilme yeteneği" değerlendirilmektedir. Öğrencinin söz konusu olan bu değişkenler arasında kurduğu ilişkisellik de ölçme-değerlendirme sürecinde etkili olmaktadır (Shih, 2018: 308). Bu noktada, Shih’in altını çizdiği gibi, çeviri yorum yazılarında, "iki dil arasındaki dilsel farklılıkları tartışmak yerine öğrencilerin karşı karşıya kaldığı, mücadele etmek durumunda olduğu ve daha çok çeviri kararlarılyla ve stratejileriyle ilgili meselelere" odaklanılması hedeflenmektedir (2018: 309).

Shih’in çeviri yorum yazllarının içeriğine ilişkin dile getirdiği görüşleriyle paralellik kuran bir diğer çalışmada ise, araştırmacı Ana Maria García Álvarez, özel alan çevirilerinde öğrencilerin kaleme aldıkları çeviri yorumlarını kavramsal bir perspektiften hareketle tartışmaya açmaktadır. García Álvarez’e göre, "belirli bir yöntemsel izlek odağında kaleme alınan yorum yazıları, öğrenciye, çeviri stratejileri geliştirmesine yönelik bilinç ve beceri kazandırmaktadır” (2007: 139). Dolayısıyla, bu doğrultuda kaleme alınan çeviri yorum yazıları, benimsenen makro ve mikro düzeydeki çeviri stratejilerini görünür kılmakta ve öğrencinin, çeviri sürecinde tutarlı bir yol izlemesini sağlamaktadır. Yazar, teknik çeviri sürecinde, öğrencinin ortaya çıkardığı çeviri ürüne ve bu ürünü yaratırken aldığı kararlar doğrultusunda "öz değerlendirme” yapabilmesinin önemini vurgulamaktadır (García Álvarez, 2007: 140). Öğrenci uygulayacağı çeviri stratejilerine karar verirken, bu süreçte sahip olduğu "özgüven” seviyesini de ortaya koymaktadır. Çeviri yorum yazıları, öğrenciye, "çeviri eyleminin karmaşık yapısına yönelik bilinç kazandırmakta, çeviri ürüne ilişkin sorumluluk almasını desteklemekte ve entelektüel anlamda öğrencinin farkındalık derecesini geliştirmektedir” (2007: 141). Çeviri yorumlarının sözel düzeyde kalmaması ve bunun sonucunda, öğrenciye teknik bir metnin çevirisini yaparken "tartışma" odaklı bir çeviri eğitimi altyapısının sunulması, öğrencinin bu süreçteki çevirmen konumunu güçlendirmektedir (García Álvarez, 2007: 142). Aslına bakılırsa, öğrencinin benimsediği çeviri kararlarını yazarak açıklaması, teknik çeviri kapsamında, öğrencinin, "deklaratif" bilgi ile "prosedürel" bilgi arasında kurduğu etkileşimi ortaya çıkarmaktadır (García Álvarez, 2007: 143). García Álvarez, öğrenciye, deneyimlediği çeviri sürecini betimlemek üzere tutarlı ve bütüncül bir yöntemin sunulmasını savunmaktadır. Öğrenci kendisini yönlendirecek yönerge eşliğinde benimsediği çeviri stratejilerini tutarlı bir biçimde yazıya dökmektedir. Bu noktada, García Álvarez teknik çeviri eğitiminde oluşturulacak olan çeviri yorum yazılarının, alternatif bir ölçme-değerlendirme aracı olarak ele alınabileceğini sözlerine eklemekte ve bu doğrultuda, öğrencinin "bilişsel düşünme" becerilerinin gelişeceğini dile getirmektedir (2007: 160).

Çeviri yorum yazılarının, bilişsel temelli düşünme becerilerini geliştirdiğini ifade eden araştırmacı Garcīa Álvarez'in ardından, çeviri eğitiminde beceri merkezli eğitim modellerini uygulayan Hurtado Albir (2007), bu çerçevede öne çıkan görev odaklı çeviri eğitimi yaklaşımlarının önemini vurgulamaktadır. Bu noktada, yazar, çeviri ürünlere yönelik kaleme alınan yorum çalışmalarında, öğrencinin çeviri sürecinde "baş ettiği sorunlar, deneyimlediği stratejiler ve çok dilli paralel metin taraması" gibi konu başlıklarını gündeme taşınmaktadır (2007: 183). Çeviri yorum yazılarını bir

Adres Address

RumeliDE Dil ve Edebiyat Araştırmaları Dergisi $\quad$ RumeliDE Journal of Language and Literature Studies Osmanağa Mahallesi, Mürver Çiçeği Sokak, No:14/8 Osmanağa Mahallesi, Mürver Çiçeği Sokak, No:14/8 Kadıköy - İSTANBUL / TÜRKIYE 34714 Kadıköy - ISTANBUL / TURKEY 34714 e-posta: editor@rumelide.com e-mail: editor@rumelide.com,

tel: +90 505 7958124, +90 2167730616 phone: +90 505 7958124, +90 2167730616 
ölçme-değerlendirme aracı olarak ele alan araştırmacı Marisa Presas (2012), Avrupa Yükseköğretim Alaninın [“European Higher Education Area”] kurulmasını hedefleyen Bologna süreciyle birlikte çeviri eğitiminde görev odaklı bakış açısının önemi vurgulanmaktadır. Bu çerçevede, araştırmacı, görev odaklı çeviri eğitimi yaklaşımının göstergesi olan çeviri yorum yazılarını, "anlamlı öğrenme" yöntemlerine dikkat çekerek açıklamaktadır (2012: 142). Anlamlı öğrenme yönteminde, öğrenci kavramsal bilgi ile donatılmakta ve bu bilgiye, karşı karşıya kaldığı sorunları çözme sürecinde başvurmaktadır. Öğrenci edindiği bu bilgilerden hareketle, yeni bilgiler yaratmak konusunda beceriler geliştirmekle yükümlüdür. Anlamlı öğrenme yaklaşımında, öğrencinin kendi öğrenme sürecine yönelik sorumluluk üstlenmesini sağlayan ve öğrenciyi bu yönde motive eden aktiviteler önem taşımaktadır. Bununla birlikte, öğrencinin “öz değerlendirme” yapabileceği ölçme-değerlendirme ortamları da anlamlı öğrenme çerçevesinde öne çlkmaktadır. Öğrencinin kendi deneyimlediği öğrenim sürecine ya da başka bir deyişle ortaya koyduğu çeviri performansına yönelik düşünce üretmesi, anlamlı öğrenme yöntemleri etrafında ele alınabilmektedir (Presas, 2012: 143). Presas, çeviri yorum yazılarını, anlamlı öğrenme stratejileri arasında değerlendirmekte ve görev odaklı eğitim yaklaşımının merkezinde konumlandırmaktadır. Çeviri yorum yazılarıyla, öğrencinin derse yönelik öğrenim çıktılarını yerine getirip getirmediği tespit edilmekte ve öğrencinin, çeviri ürün odağında yürüttüğü değerlendirme ve öz değerlendirme sürecine ilişkin anlamlı geri dönüşler elde edilmektedir. Aynı zamanda, öz yönetim ve öz kontrol gibi unsurları güçlendiren görev odaklı çeviri yaklaşımı, anlamlı öğretim ilkelerine de uyum sağlamaktadır. Öğrencilerin kaleme aldıkları çeviri yorum yazılarının, sözü edilen bu çerçevede ölçülüp değerlendirilmesi, bu sürecin "şeffaflığına, geçerliliğine ve güvenirliliğine" tanıklık etmektedir (Presas, 2012: 152-153). Çeviri yorum yazılarını "sorun çözme" temelli bir etkinlik ve eleştirel düşünceyi geliştiren "keşfederek öğrenme” yöntemi olarak ele alan Presas’a göre, öğrencinin sözü edilen bu pratiği deneyimlerken yerine getirmekle sorumlu olduğu üç görevi bulunmaktadır. Bu görevler sırasıyla, "kaynak metnin çözümlenmesi", "kaynak metnin çevirisi" ve "çeviri sorunları üzerine düşünme" olarak kavramsallaştırılmaktadır (2012: 153).

Çeviri yorum yazılarının önemini gündeme taşıyan çalışmalara Türkiye perspektifinden bakıldığında, araştırmacı Senem Öner Bulut'un bu yönde gerçekleştirdiği araştırmadan söz edilebilmektedir. Araştırmacı, günümüz koşulları doğrultusunda çeviri eğitimi yöntemlerinin yeniden yapılanmasına dikkat çekmektedir. Bunu yaparken de, çevirmenin görünür kimliğini, öğrenci merkezli çeviri eğitim yaklaşımları çerçevesinde gündeme taşımaktadır. Bu çerçevede, çeviri eğitiminde çok yönlü yaklaşımların önemini vurgulayan yazar gerçekleştirdiği saha çalışmasında, öğrencilerin ürettikleri çeviri metinlere yönelik kaleme aldıkları yorum yazılarını ele almaktadır (2018: 25). Araştırmacı, gerçekleştirdiği saha çalışması sonucunda, ilgili yorum yazılarının, bir taraftan çevirmeni karar alan bir “özne” olarak güçlendirdiğini ifade ederken, diğer taraftan ise bu süreçte öğrencilerin üstlendikleri "aktif” rol ile çevirmenin görünürlüğüne ilişkin bilinçlerinin ve öz farkındalıklarının geliştiğini gündeme taşımaktadır (2018: 36).

\section{Uygulama sahası: Gig Ekonomisi etrafından şekillenen çeviri odaklı (öz)düşünümsel öğrenci performansları}

Yıldız Teknik Üniversitesi Batı Dilleri ve Edebiyatları Bölümü Fransızca Mütercim ve Tercümanlık Bölümü’nde 2020-2021 eğitim-öğretim yll güz döneminde yürütülmüş olan MTF 2141 Teknik Çeviri 1 dersi kapsamında, öğrencilere teknik çevirinin ilkelerinin ve aşamalarının öğretilmesi amaçlanmaktadır. Bununla birlikte, ilgili ders, farklı teknik metin niteliklerinin tanıtılması, teknik çeviri sürecinde grup çalışmalarının yapılması, paralel metinlerin taranması ile terim araştırmalarının gerçekleştirilmesi ve erek metnin oluşturulması gibi aşamalar çerçevesinde yürütülmektedir. İlgili

\begin{tabular}{r|l} 
Adres & Address \\
RumeliDE Dil ve Edebiyat Arastrmalart Dergisi & RumeliDE
\end{tabular}

Osmanağa Mahallesi, Mürver Çiçeği Sokak, No:14/8 Osmanağa Mahallesi, Mürver Çiçeği Sokak, No:14/8

Kadıköy - İSTANBUL / TÜRKIYE 34714 Kadıköy - ISTANBUL / TURKEY 34714

e-posta: editor@rumelide.com e-mail: editor@rumelide.com,

tel: +90 505 7958124, +90 216773 o 616 phone: +90 505 7958124, +90 2167730616 
dersin öğrenim çıtılarına bakıldığında, öğrencinin teknik çeviri alanında farkındalık kazanması amaçlanmaktadır. Bunu yaparken, öğrenciden, terim tablosu oluşturabilmesi ve çok dilli paralel metin ve içerik araştırma çalışmaları yapabilme becerileri geliştirmesi beklenmektedir. Öğrencinin teknik çeviri metni oluşturmaya yönelik yetiler kazanması, söz konusu olan dersin öğrenim çıktıları arasında yer almaktadır3.

Sözü edilen ders kapsamında gerçekleştirilen final sınavına 37 öğrenci katılmıştır. Final sınavının başarı ortalaması 100 üstünden 86,6'dır. Not dağılımına bakıldığında, 18 öğrenci 90-100 arası, 11 öğrenci 80-89 arası, 3 öğrenci 70-79 arası, 1 öğrenci 60-69 arası, 4 öğrenci ise 50-59 arasında not almıştır. Final sınavı uzaktan eğitim sistemi üzerinden yapılmıştır. İki sorudan oluşan final sınavında, öğrencilerden Gig Economy: des travailleurs du clic à l'économie des petits boulots ${ }^{4}$ başlıklı Fransızca kaynak metnin Türkçeye çevirisinin yapılması ve daha sonrasında ise üretilen erek metne yönelik öğrencilerden "çevirmen ön sözü" olarak adlandırılan Türkçe çeviri yorum yazıları oluşturulması istenmiştir. Sınavın puanlamasında, birinci soruya 60 puan, ikinci soruya ise 40 puan verilmiştir. $\mathrm{Bu}$ çalışma kapsamında, sınava katılan tüm öğrencilerin kaleme aldıkları ilgili çeviri yorum yazılarına yer vermek mümkün olamayacağı için en iyi notu alan beş öğrencinin5 sınav kağıtlarının çözümlenmesine karar verilmiştir. Araştırma örneklemini oluşturan beş öğrenci ürettikleri çeviri yorum yazılarıyla, yukarıda belirtilen ilgili dersin öğrenim çıktılarını yerine getirmektedirler. Sözü edilen bu kriter de beş öğrencinin sınav kağıtlarının seçilmesinde etkili olmuştur.

Çeviri yorum yazısını oluşturmak için yol gösterici niteliğe sahip altı maddeden oluşan bir yönerge öğrencilerle paylaşılmıştır. İlgili yönerge sırasıyla şu aşamalardan oluşmaktadır:

1. Kaynak metnin konusunun belirlenmesi,

2. Terimler ışı̆̆ında kaynak metindeki çatı alanın ve alt alanların tespit edilmesi,

3. Çoklu medya ortamlarında yürütülen çok dilli paralel metin araştırmasının sonuçlarının paylaşılması,

4. Otomatik çeviri programlarıyla yaşanan deneyimin eleştirel boyutta sorgulanması,

5. Benimsenen çeviri kararlarının açıklanması ve terimlerin çevirisinde başvurulan stratejilerin örnekler ışı̆ı̆nda irdelenmesi,

6. Çeviri sürecine yönelik sonuç gözlemlerinin ifade edilmesi.

Aşağıda yer verilen beş öğrencinin ürettiği çeviri yorum yazıları yukarıda vurgulanan kavramsal ve yöntemsel çerçeve kapsamında değerlendirilmektedir. Bu bağlamda, "katılımcı nesneleştirme, öz yönlendirme, etik sorumluluk, keşfederek öğrenme, kendini izleme, bilişsel düşünce, yansıtma, kuram-uygulama sinerjisi, sorun çözme, öz değerlendirme, öz yönetim, bilimsel akıl yürütme, entelektüel farkındalık, deklaratif-prosedürel bilgi etkileşimi, anlamlı öğrenme” gibi özdüşünümsel performans sergileme biçimlerini tanımlayan kavramların izleri, öğrencilerin kaleme aldıkları çeviri yorum yazılarında sürülmektedir ${ }^{6}$.

3 İlgili derse yönelik bilgiler için bkz. http://bologna.yildiz.edu.tr/index.php?r=course/view\&id=4152\&aid=8.

4 İlgili metne ulaşmak için bkz. http://courriercadres.com/high-tech/nouvelles-technologies/gig-economy-destravailleurs-du-clic-a-leconomie-des-petits-boulots-05072019.

5 Calışma kapsamında, ilgili öğrencilerin onanmıs rızaları alınmıștır. Çözümleme cerçevesinde, öğrenciler, 1 numaralı öğrenci, 2 numaralı öğrenci, 3 numaralı öğrenci, 4 numaralı öğrenci ve 5 numaralı öğrenci olarak adlandırılmaktadır. Bu öğrencilerin sırasıly isimleri ve soyadları şu şekildedir: Gizem Mutlu, Cihan Sevindik, Gülseren Sayar, Ece Küçük ve Omer Faruk Türkmen.

6 Saha çalışması kapsamında, ilgili öğrencilerin kaleme aldıkları çeviri yorum yazılarından kesitler paylaşılmıştır. Söz konusu çeviri yorum yazılarının tamamına Ek 1., Ek 2., Ek 3., Ek 4. ve Ek 5.’de yer verilmektedir.

Adres Address

RumeliDE Dil ve Edebiyat Araşttrmaları Dergisi $\quad$ RumeliDE Journal of Language and Literature Studies Osmanağa Mahallesi, Mürver Çiçeği Sokak, No:14/8 Osmanağa Mahallesi, Mürver Çiçeği Sokak, No:14/8

Kadıköy - İSTANBUL / TÜRKIYE 34714 Kadıköy - ISTANBUL / TURKEY 34714 e-posta: editor@rumelide.com e-mail: editor@rumelide.com,

tel: +90 505 7958124, +90 216773 o 616 phone: +90 505 7958124, +90 216773 o 616 
İlgili öğrencilerin oluşturdukları çeviri yorum yazılarına yakın plan bakıldığında, 1 numaralı öğrencinin kaynak metnin konusuna ilişkin kısa bir bilgilendirme yaptığı görülmektedir. Terim düzeyinde verdiği örnekler odağında, öğrenci metnin çatı alanını "işletme" olarak belirlediğini, alt alanlarını ise "proje yönetimi, iş etiği ve pazarlama" olarak tespit ettiğini şu şekilde ifade etmektedir:

"Final ödevi kapsamında çevirisini yaptığımız metinde, dijitalleşme ile birlikte değișen dünyanın getirilerinden biri olan yeni bir ekonomik modelden söz ediliyor. Mise sur le marché, innover, paiement à l'acte, revenu complémentaire, service de livraison şeklinde örnek verebileceğim bazı terimler de metnin işletme alanına ilişkin olduğunu yeniden ortaya koyuyor. Metinde proje yönetimi, iş etiği, iş nitelikleri, pazarlama şeklinde alt alanlara ait kelimeler bulunuyor.” (Öğrenci 1)

Öğrenci, çeviri sürecinde benimsediği çeviri stratejilerini, “yabancı kelimeler için Türkçe karşlıklar üretmeye çalıştım” diyerek ifade etmektedir. Kimi yerlerde “dipnot”lar kullandığını sözlerine ekleyen ilgili öğrenci, bu doğrultuda "inisyatif” sözcüğüne vurgu yaparak sorun çözme kapasitesini ortaya koymaktadır. Bu çerçevede, öğrenci, yeni bilgiler yaratma konusunda sorumluluk üstelendiğini dile getirerek, "anlamlı öğrenme" sürecini deneyimlediğini şu şekilde gündeme taşımaktadır:

"Metin güncel bir konuya ait olduğu için henüz terminoloji tam yerleşmemiş. Bu sebeple de çevirmenin insiyatif kullanmasının mümkün olduğundan bahsedebiliriz. Türkçe içinde yabancı kelimelere yer vermekten çok haz etmediğim için elimden geldiğince karşılık üretmeye çalıştım.” (Öğrenci 1)

Bunun yanı sıra, ilgili öğrenci otomatik çeviri programlarıyla yaşadığı deneyimde "sorgulayıcı ve eleştirel” bir üst bakış geliştirdiğini aşağıda yer alan cümlelerle tartışmaya açmaktadır:

\begin{abstract}
"Karşılaştığım bir problem ve çözüm yolunda yardımcım olan çeviri programlarını kullanma şeklimi bir örnekle açılayacağım. "Ils nourrissent les bases de données d'entreprises" cümlesini anlamlandırsam da alana ilişkin kullanımda "veritabanlarının NE yapılacağı" konusunu ifade edemedim. Bunu öğrenmek için tureng.com üzerinden "database" kelimesini arattım. tureng.com'da bu kelimenin diğer terimlerle birlikte alana ait kullanımları da listelendiği için elimdeki veriye uygun bir anlam aradım.” (Öğrenci 1)
\end{abstract}

Çözümleme çalışmasına 2 numaralı öğrenciyle devam edildiğinde, kaynak metnin genel konusuna aşağıda yer alan yorum yazısında yer verilmektedir. İlgili öğrenci kaynak metnin çatı alanını "dijital finansal okuryazarlık", alt alanlarını "esnek ekonomi, bilişim ve internet” olarak belirlediğini şu açıklamalarla dile getirmektedir:

"Metnin başından sonuna kadar "esnek ekonomi” üzerinde durması sebebiyle çatı alan önerim
"esnek ekonomi”, ancak esnek ekonomi terimi tek başına incelendiğinde alanını "dijital ekonomi”
değil, "dijital finansal okuryazarlık" olarak belirledim. Alt alanlar örnek terimlerle: esnek ekonomi
(esnek ekonomi,odd-jobs, clickworkers, çevrimiçi serbest çalışanlar) bilişim (yapay zekâ), bilgi ve
iletişim teknolojileri (dijital ekonomi), internet (kitle kaynak) olarak sıralanabilir." (Öğgrenci 2)

Öğrenci, çeviri aşamasına geçmeden önce "terim araştırması" yaptı̆̆ını söyleyerek, "bilimsel ve yöntemsel düzeyde akıl yürütme” sürecini yerine getirdiğini ortaya koymaktadır. Çoklu medya ortamlarında çok dilli paralel metin taraması yaptığını da sözlerine ekleyen öğrenci, benimsediği makro ve mikro düzeydeki stratejilerle, kuram ve uygulama alanları arasında kurduğu ilişkiselliği ve sinerjiyi şu ifadelerle gözler önüne sermektedir:

“Terim tablosu oluşturmadan verimli bir çeviri yapacağımı düşünmediğimden terim tablosu oluşturdum ve saptadığım terimleri alanına göre terim anlamları bulabileceğim çevrimiçi kaynaklar ve bulduğum Türkçe, Fransızca ve yoğunlukla İngilizce paralel metin taramalarından aldığım bilgilerle tanımladım. Dilimize İngilizce olarak geçmiş Fransızca -özellikle paralel metinlerde de İngilizce olarak kullanılmış- terimleri yine paralel metinler ışı̆̆ında terimin kaynak dilinde de erek

\begin{tabular}{|c|c|}
\hline Adres & Address \\
\hline ¡DE Dil ve Edebiyat Araştırmaları Dergisi & RumeliDE Journal of Language and Literature Studies \\
\hline kak, No: & er Çiçeği Sokak, No:14/8 \\
\hline $\begin{array}{r}\text { Kadıköy - İSTANBUL / TÜRKIYE } 34714 \\
\text { e-posta: editor@rumelide.com } \\
\text { tel: +90 } 5057958124,+902167730616\end{array}$ & $\begin{array}{l}\text { Kadıköy - ISTANBUL / TURKEY } 34714 \\
\text { e-mail: editor@rumelide.com, } \\
\text { phone: +90 505 7958124, +90 } 216773 \text { o } 616\end{array}$ \\
\hline
\end{tabular}


metinde kullanılabildiğini düşündüm ancak bazı terimler için çevirmen notuyla da açıklayabileceğim şekilde Türkçeleştirme yolunu tercih ettim.” (Öğrenci 2)

İlgili öğrenci düşünümsel bir farkındalıkla otomatik çeviri programlarını sınadığını "düzeltme işlemi yaptım” diyerek kanıtlamaktadır. Teknik çeviri sürecinde, "yeni bilgiler yaratma” ve "araştırma yapmanın” önemini vurgulayan öğrencinin kaleme aldığı çeviri yorum yazısına şu şekilde devam etmektedir:

"Bir yapay zekâ girişimi olduğunu düşündüğüm Google Çevirinin, - metnin içeriğinde yapay zekadan bahsedildiği gibi yeterince gelişmemiş olduğunu - insan zekasının yerini alamayacağını düşündüm bu sebeple de oluşturulan sonuç üzerinde düzenlemelerim oldukça fazlaydı.” (Öğrenci 2)

Çözümleme çerçevesinde ele alınan bir diğer çeviri yorum yazısı 3 numaralı öğrenci tarafından kaleme alınmıştır. Yukarıda sözü edilen diğer öğrenciler gibi, bu öğrenci de kaynak metnin konusuna ilişkin bilgi vererek çeviri yorum yazına başlamıştır. Öğrenci, metnin alan ve alt alanlarını örnekler odağında tartışmaya açtıktan hemen sonra yürüttüğü çok dilli içerik taramasını şu şekilde gündeme getirmiştir:

“Metnin genel alanı 'ekonomi’ ye dayanıyor. Alt alan bazında genel olarak 'teknoloji' alanında terimler yer alıyor. Bu alt alana örnek verecek olursak 'Yapay zekâ' nın metinde yer yer geçtiğini göreceksiniz ya da 'mikro-iş' ve 'maliyet' gibi alt alanı 'ekonomi' olan terimleri... Paralel metin kapsamında varış dilinden çok İngilizce yazılmış daha çok metine ulaşmak mümkün.” (Öğrenci 3)

İlgili öğrenci otomatik çeviri programlarıyla deneyimlediği sürece ilişkin, "biraz düşünmem ve konuya ilişkin en doğru kelimeyi seçmem gerekiyor” demeyi tercih etmişti. Bu noktada, öğrenci benimsediği çevirmen kimliğini de nesnel bir bakış açısıyla sorguladığını şu ifadelerle belirtmektedir:
“Çeviri aşamasında doğru anlam ve kelimeyi yakalamak için kullandığım birkaç online sözlük mevcut ve bunlar doğruluğundan \%95 emin olduğum kaynaklar. Sadece çıkan sonucun üzerinde biraz düşünmem ve konuya ilişkin en doğru kelimeyi seçmem gerekiyor. Bu seçimleri de genellikle çok dilli bir araştırmayla elde ediyorum.” (Öğrenci 3)

Terimlerin çevirisine yönelik aldığı kararların, "keşfederek öğrenme" yaklaşımına dayandığını da ortaya koyan ilgili öğrenci çeviri yorum yazısına şu şekilde devam etmektedir:
"Metinde izlediğim çeviri stratejisi genel olarak kelimeleri Türkçe karşılıklarıyla yazmaktı fakat birkaç yerde özellikle İngilizce kelimeleri olduğu gibi bırakmayı seçtim. Çünkü kaynak metindeki bazı yerlerde terimleri kendim oluşturdum ve bilmeyen ya da anlayamayanlar için İngilizce karşılığından çağrışım yapabileceklerini düşündüm.” (Öğrenci 3)

4 numaralı öğrencinin oluşturduğu çeviri yorum yazısı incelediğinde, kaynak metnin konusuna ilişkin bilgilendirmenin yapıldığı görülmektedir. Çatı alanı, "dijital ekonomi ve finans" olarak belirleyen öğrenci, terimlerin çevirisinde "çevirmen olarak bazı kararlar almak durumunda kaldım" ifadesine başvurmaktadır. Bu noktada, öğrencinin, üstlendiği çevirmen kimliğine yönelik geliştirdiği bilimsel farkındalık ve sorumluluk şu ifadelerle görünür kılınmaktadır:

\begin{abstract}
"İlk kısımda anlatmış olduğum gibi bu teknik metin dijital ekonomi ve finans çatı alanlarından oluşmaktadır. Bu durumda alana dijital ekonomi ya da finans olarak alabilirken, alt alanları ise: teknoloji, yapay zekâ gibi örnekler ile çeşitlendirilebilir. Örneğin: "IA", "base de donnée" terimlerini bu alt alanlara örnek olarak verebiliriz.” (Öğrenci 4)
\end{abstract}

İlgili öğrenci, "terim tablosu oluşturdum ve paralel metin çalışması yaptım” gibi ifadeleri kullanarak, teknik çeviri sürecinde deneyimlediği bilimsel aşamalar arasında ilişkisellik kurduğunu ve yürüttüğü bu süreçte benimsediği kuramsal ve yöntemsel yaklaşımı şu şekilde açılamaktadır:

\footnotetext{
Adres $\mid$ Address

RumeliDE Dil ve Edebiyat Araştırmalar Dergisi $\quad$ RumeliDE Journal of Language and Literature Studies Osmanağa Mahallesi, Mürver Çiçeği Sokak, No:14/8 Osmanağa Mahallesi, Mürver Çiçeği Sokak, No:14/8 Kadıköy - İSTANBUL / TÜRKIYE 34714 Kadıköy - ISTANBUL / TURKEY 34714 e-posta: editor@rumelide.com e-mail: editor@rumelide.com tel: +90 505 7958124, +90 2167730616 phone: +90 505 7958124, +90 2167730616
} 
"Her ne kadar kısa bir metin olsa da bu çeviride terim çalışması yapmadan hiçbir şekilde çalıșamazdım ve bu yüzden terim tablosu oluşturdum ve bununla birlikte paralel metin çalıșmamı gerçekleştirdim. Paralel metin araştırmalarımda hem Türkçe hem İngilizce birçok kaynağa ulaştım.” (Öğrenci 4)

Bununla birlikte, öğrenci, erek metne "yeni kavramlar" eklediğini dile getirmekte ve hem anlamlı öğrenme, hem de keşfederek öğrenme yöntemlerine başvurduğunu şu cümlelerle göstermektedir:

“Esnek Ekonomi(Gig economy) iş dünyasının yeni kavramı olduğu için bazı kavramlar Türkçe de kesin olarak çevrilmediği veya yeni tanımlanmış bir kavram olduğu için çevirmen olarak bazı terimlerde kararlar almak durumunda kaldım. Fakat ilk başta da dediğim gibi Esnek Ekonomi hakkında Türkçe de ulaşamadığım terimler oldu, bu terimlerde kelimenin Fransızcasını ekleyip çevirmen notu ile destekledim.” (Öğrenci 4)

İlgili öğrenci otomatik çeviri programlarını deneyimlerken yaşadığı süreci “yaratıcılık” kavramına vurgu yaparak şu şekilde ifade etmektedir:

"Ek olarak, çeviri sürecimde, "yandex çeviri” veya "google translate” otomatik çeviri programlarını önerilerine baktım. Sonuç olarak çevirmenin yaratıcılığı, kültürel entonasyonlarını bile düşünürken otomatik çevirilerin hiçbir zaman yaratıcı olmayacağı gibi aynı kaynak metin'deki aynı hissiyatı vermeyeceğini düşünmekteyim.” (Öğrenci 4)

Saha çalışması kapsamında yer alan son öğrencinin kaleme aldığı çeviri yorum yazısı yakından incelediğinde, kaynak metnin konusunu oluşturan "gig ekonomisi" kavramının ilgili öğrenci tarafından açıllandığı görülmektedir. Alan ve alt alan ayrımını örnekler üzerinden sorgulayan öğrenci yazısına şu sözlerle başlamaktadır:

"Metnin ana alanı Ekonomiydi. Bu alan doğrultusunda alt alanlar ise yeni iş modeli olan Esnek ekonomi ve Teknolojiydi. Bu alt-alanlara örnek olarak Esnek ekonomi için "Clickworker", "Freelancer" ve "Mikro-iş" terimleri örnek verilebilir.” (Öğrenci 5)

Sözü edilen öğrenci, benimsediği çeviri stratejilerini açımlarken, "okur ile erek metin arasında köprü kurmayı" hedeflediğini sözlerine eklemektedir. Bu noktada, sözü edilen öğrenci, çeviri metnini oluştururken topluma ve bireye dokunduğuna şu ifadelerle dikkat çekmektedir:

"Çeviri sırasında birçok kez tırnak içindeki anlatımı vermek için eklemelerde bulundum. Dilimize geçmiş bazı terimleri olduğu gibi bıraktım. Yani orijinal metinde ve bağlamda var olan terimi okurlara bu şekilde götürmek ve bu şekilde bir köprü kurmak istedim.” (Öğrenci 5)

İlgili öğrenci, otomatik çeviri araçları kapsamında elde ettiği sonuçları gözden geçirdiğini belirterek, deklaratif bilgi ile prosedürel bilgi arasında kurduğu etkileşimi şu kavramlar etrafında dile getirmektedir:

“Çeviri motorlarını kullandığım zaman genelde sadece kelimelere bakıyorum veya nasıl bir yol izlemiş diye kontrol ediyorum. Bazen çeviri motorlarını İngilizceden Fransızcaya veya tam tersi şekilde kullanıyorum. Bunun dışında genellikle larousse gibi siteleri kullanıyorum ve en çok yararlandığım fakat hala Türkçe dilinin beta aşamasında olan Reverso sitesi var.” (Öğrenci 5)

Görüldüğü üzere, araştırma örnekleminde yer alan öğrencilerin kaleme aldıkları çeviri yorum yazıları, özdüşünümsel farkındalıkla oluşturulan yansıtıcı rapor niteliğinde çalışmalar olarak değerlendirilebilmektedir. İlgili öğrenciler ürettikleri çeviri yorum yazılarında, kaynak metnin çözümlemesini yaptıklarını ortaya koymaktadırlar. Bununla birlikte, öğrenciler uyguladıkları çeviri kararlarını ve stratejilerini örnekler üzerinden irdelerken, karşlaştıkları sorunlara yönelik geliştirdikleri sorun çözme becerilerini, ilgili çeviri yorum yazılarında göstermektedirler. Kuramsal ve

\footnotetext{
Adres
RumeliDE Dil ve Edebiyat Araşttrmaları Dergisi Osmanağa Mahallesi, Mürver Ciçeği Sokak, No:14/8 Kadıköy - İSTANBUL / TÜRKIYE 34714 e-posta: editor@rumelide.com

Address

RumeliDE Journal of Language and Literature Studies

Osmanağa Mahallesi, Mürver Çiçeği Sokak, No:14/8

Kadıköy - ISTANBUL / TURKEY 34714

e-mail: editor@rumelide.com,

tel: +90 505 7958124, +90 216773 o 616 phone: +90 505 7958124, +90 2167730616
} 
yöntemsel bilgi birikimini yansıtan bu yöndeki çalışmalarda, öğrenciler çoklu medya ortamlarında çok dilli paralel metin taraması yaptıklarını ifade etmektedirler. Aynı zamanda, sözü edilen öğrenciler, dijital çeviri araçlarını deneyimlerken ürettikleri eleştirel ve sorgulayıcı düşünce biçimlerini de, ilgili çalışmalarda tartışmaya açmaktadırlar.

\section{Sonuç}

Görüldüğü üzere, ilgili araştırma kapsamında teknik metin çevirmeni, çoklu medya ortamlarını deneyimleyen ve çok dilli iletişim ağlarını kuran mühendis konumunda yer almaktadır. Bu çerçevede, araştırma örneklemini oluşturan öğrencilerin, yeni bilgi ve deneyim alanları doğrultusunda, "bilgiye ulaşma ve yönetme, terim yaratma ve yönetme ile teknik metin yazma" gibi performanslar geliştirdikleri görülmektedir. Çalışma çerçevesinde gündeme getirilen araştırma sorularına geri dönüldüğünde, uygulama sahası kapsamında gerçekleştirilen tematik çözümleme ışığında, ilgili öğrencilerin kaleme aldıkları çeviri yorum yazılarıyla, anlamlı ve keşfederek öğrenme becerileri geliştirdikleri görülmektedir. Aynı zamanda, ilgili öğrencilerin çeviri yorum yazıları etrafında yükselen performansları, öz yönetim ve öz kontrol gibi yeteneklerini ortaya koymaktadır. Bunun yanı sıra, öğrencilerin teknik çeviri sürecinde deneyimledikleri bilişsel düşünme pratikleri görünür kılınmaktadır. Çeviri yorum yazılarıyla özne konumunda aktif rol üstlenen öğrencilerin, ilgili final sınavı çerçevesinde inşa ettikleri çevirmen kimliklerine ilişkin farkındalık kazanmaları ve sorumluluk üstlenmeleri, bu doğrultuda benimsedikleri çevirmen kimliklerini güçlendirmektedir. Dolayısıyla, beş öğrencinin kaleme aldıkları yorum yazıları ile özdüşünümsel performans sergileme nitelikleri ve biçimleri arasında kurulan ilişkisellikten söz etmek mümkün olabilmektedir.

$\mathrm{Bu}$ veriler ışığında, çalışma kapsamında, çeviri yorum yazıları görev odaklı etiğim yaklaşımının bir örneği olarak anlam kazanmaktadır. Öğrenciler, makro ve mikro düzlemde aldıkları çeviri kararları arasındaki etkileşim ile deklaratif bilgi ve prosedürel bilgi arasında kurdukları diyaloğu gözler önüne sermektedirler. Öğrenciler, çevirmen ön sözlerinde geliştirdikleri düşünümsel algıyla, ürettikleri erek metinle kurdukları ilişkiyi ortaya koymaktadırlar. Öğrenciler, bu ilişkiyi nasıl kurguladıklarının, kendi çevirmen kimliklerini nasıl sorguladıklarının ve araştırma konusu ile yani erek metin ile aralarında nasıl bir boşluk bıraktıklarının farkındadırlar. Söz konusu öğrenciler, teknik çeviri sürecini düşünürken ve bu süreci deneyimlerken, teknik çevirinin aşamaları arasında ilişkisellik kurmaktadırlar. Öğrenciler uyguladıkları çeviri stratejilerinde ve kararlarında, odaklandıkları kuramsal ve yöntemsel dayanakları açıça dile getirmektedirler. Bunu yaparken, çeviri eyleminin topluma ve bireye dokunan niteliğini göz önünde bulundurmaktadırlar. Öğrenciler, yaşadıkları sorunlarla yüzleşerek ve hesaplaşarak, bunları sorgulayarak, bunlara ilişkin keşfettikleri çözüm yollarını ve çeviri süreci deneyimlerini paylaşarak, etik düzlemde sorumluluklarını yerine getirmektedirler. Yeni medya çevirmeni olan bu öğrenciler, çeviri sorunlarının çözümüne ilişkin, yeni yolların ve yeni bakış açılarının var olabileceğini çeviri yorum yazılarında açıç̧a vurgulamaktadırlar. Sonuç olarak, teknik çeviriyi, katılımcı bir nesneleştirme performansı olarak kurgulayan öğrencilerin, bu süreçte başvurdukları çeviri yöntemlerini ve stratejilerini özdüşünümsel bir kavrayış ile sınadıkları görülmektedir.

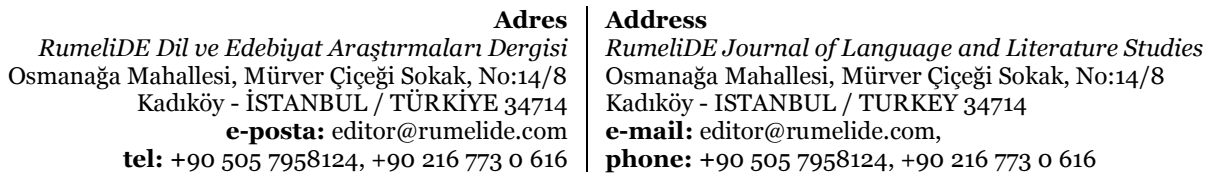




\section{Kaynakça}

Binark, M. (2005). İnternet’i ve Bilgisayar Dolayımlı İletişim Ortamlarını İncelemek İsteyen Bir Araştırmacının Soruları ve Sorunları. Mutlu Binark, Barış Kılıçbay (Ed.), İnternet, Toplum, Kültür içinde (s. 177-190). Ankara: Epos.

Binark, M. (2014). Yeni Medya Çalş̧malarında Araştırma Yöntem ve Teknikleri. İstanbul: Schola Ayrintı.

Bourdieu, P. ve Wacquant, L. (2007). Düşünümsel Bir Antropoloji için Cevaplar. Çev. Nazlı Ökten İstanbul: İletişim.

Durieux, C. (1988). Fondement didactique de la traduction technique. Paris: Didier.

EMT European Master's in Translation. (2017). EMT Competence Framework.https://ec.europa.eu/info/sites/info/files/emt_competence_fwk_2017_en_web.pd f [Erişim tarihi: 30/03/2021].

Galán-Mañas, A. ve Hurtado Albir, A. (2015). Competence Assessment Procedures in Translator Training. The Interpreter and Translator Trainer, 9(1), 63-82.

Garcīa Álvarez, A. M. (2007). 'Evaluating Students' Translation Process in Specialised Translation: Translation Commentary. The Journal of Specialised Translation, 9, 139-163.

Gouadec, D. (2002). Profession: traducteur. Paris: La Maison du dictionnaire.

Hurtado Albir, A. (2007). Competence-based Curriculum Design for Training Translators. The Interpreter and Translator Trainer, 4(3), 163-195.

Kelly, D. (2005). A Handbook for Translator Trainers. Manchester: St. Jerome.

Kiraly, D. (2000). A Social Constructive Approach to Translation Education: Empowerment from Theory to Practice. Manchester: St Jerome.

Kiraly, D. (2003). From Teacher-Centred to Learning-Centred Classrooms in Translator Education: Control, Chaos or Collaboration?. Innovation and E-Learning in Translator Training: Reports on Online Symposia. Tarragona: Universitat Rovira I Virgili, 27-31.

Öner Bulut, S. (2018). Training Translators as Subjects. Seda Taş (Ed.), Çeviribilimde Güncel Tartışmalardan Kavramsal Sorgulamalara için (s. 13-42). İstanbul: Hiperlink.

Presas, M. (2012). Training Translators in the European Higher Education Area: A Model for Evaluating Learning Outcomes. The Interpreter and Translator Trainer, 6(2), 38-169. doi: 10.1080/13556509.2012.10798834.

Schäffner, C. (2001). Annotated Texts for Translation: English-German, Functionalist Approaches Illustrated. Clevedon Avon: Multilingual Matters.

Shei, C.-C. (2005). Translation Commentary: A Happy Medium between Translation Curriculum and EAP. System, 33, 309-325.

Shih, C. Y.-Y. (2018). Translation Commentary Re-examined in the Eyes of Translator Educators at British Universities. JoSTrans: The Journal of Specialised Translation, 30, 291-311.

Tunç, S. (2014). Yeni Medya Ortamlarında Araştırma Etiği ve Özdüşünümsellik. Mutlu Binark (Der.) Yeni Medya Çahş̧malarında Araştırma Yöntem ve Teknikleri içinde (s. 171-202). İstanbul: Schola Ayrintı.

Wacquant, L. (2012). Ruh ve Beden: Acemi Bir Boksörün Defterleri. Çev. Nazlı Ökten. İstanbul: Boğaziçi Üniversitesi.

Xiang, W. (2004). Encouraging Self-Monitoring in Writing by Chinese Students. ELT Journal 58(3), 238-246.

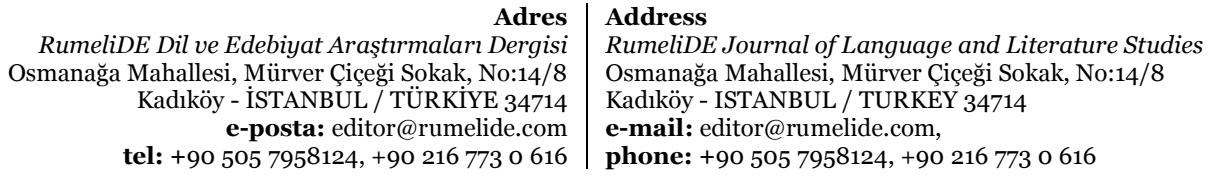




\section{Ekler}

\section{Ek 1.}

\section{1 numaralı öğrencinin kaleme aldığı çeviri yorum yazısı}

"Final ödevi kapsamında çevirisini yaptığımız metinde, dijitalleşme ile birlikte değişen dünyanın getirilerinden biri olan yeni bir ekonomik modelden söz ediliyor. Metinde bu ekonomik modellerin prensiplerini benimsemiş çeşitli şirketlere örnekler verilerek bu şirketlerin sağladıkları hizmetlerden ve çalışma koşullarından bahsedildiğinden metnin işletme alanında olduğundan söz edebiliriz. Mise sur le marché, innover, paiement à l'acte, revenu complémentaire, service de livraison şeklinde örnek verebileceğim bazı terimler de metnin işletme alanına ilişkin olduğunu yeniden ortaya koyuyor. Metinde proje yönetimi, iş etiği, iş nitelikleri, pazarlama şeklinde alt alanlara ait kelimeler bulunuyor. Metin güncel bir konuya ait olduğu için henüz terminoloji tam yerleşmemiş. $\mathrm{Bu}$ sebeple de çevirmenin insiyatif kullanmasının mümkün olduğundan bahsedebiliriz. Türkçe içinde yabancı kelimelere yer vermekten çok haz etmediğim için elimden geldiğince karşllık üretmeye çalıştım. "Crowdsourcing" kelimesi Türkçeye "free-lancing" kadar yerleşmediğinden ve "kitle kaynak" şeklinde güzel bir çevirisine de denk geldiğimden metinde İngilizce olarak bırakmadım. "Clickworker" ve "travailleur du clic" terimlerini aynı mantıkta Türkçeye çevirerek dipnotta orijinallerini de belirtmeyi ihmal etmeden yeni bir çeviri önerisi sundum. Karşılaştı̆̆ım bir problem ve çözüm yolunda yardımcım olan çeviri programlarını kullanma şeklimi bir örnekle açılayacağım. "Ils nourrissent les bases de données d'entreprises" cümlesini anlamlandırsam da alana ilişkin kullanımda "veritabanlarının NE yapılacağı" konusunu ifade edemedim. Bunu öğrenmek için tureng.com üzerinden "database" kelimesini arattım. tureng.com'da bu kelimenin diğer terimlerle birlikte alana ait kullanımları da listelendiği için elimdeki veriye uygun bir anlam aradım. Aklıma en çok yatanı google'da aratarak sağlamasını yapmış oldum ve "veritabanlarının tutulması ve güncellenmesi" olarak çevirdim. Güncel ve tartışmalı bir konu olduğu için paralel okumalar yapmak hem gerekli, hem de benim için bir tercihti. Okumalar, bu konuya farklı perspektiflerle yaklaşmamı sağladı. Genelde farklı kişilerce kaleme alınmış öznel nitelikte yazılar okudum. Cevirmekte zorlandığım yerler (özellikle son paragraf) olsa da genel olarak kolay bir metindi. Konusu da ilgi çekici ve güncel olduğundan ödevi keyifle tamamladım."

\section{Ek 2.}

\section{2 numaralı öğrencinin kaleme aldığı çeviri yorum yazısı}

"Gig Economy : des travailleurs du clic à l'économie des petits boulots" başlıklı teknik metin içerik üreticileri ve tüketicileri; kolay ve hılı bir şekilde bir araya getiren yeni bir iş şekli Esnek Ekonomi'nin; az eğitim gerektiren küçük işler yapanları tanımlayan "Odd-Jobs" ve mikro görevler yapan "çevrimiçi serbest çalışanların" katkılarıyla büyümesini anlatıyor. Metnin başından sonuna kadar "esnek ekonomi” üzerinde durması sebebiyle çatı alan önerim "esnek ekonomi”, ancak esnek ekonomi terimi tek başına incelendiğinde alanını "dijital ekonomi” değil, "dijital finansal okuryazarlık" olarak belirledim. Alt alanlar örnek terimlerle: esnek ekonomi (esnek ekonomi,oddjobs, clickworkers, çevrimiçi serbest çalışanlar) bilişim (yapay zekâ), bilgi ve iletişim teknolojileri (dijital ekonomi), internet (kitle kaynak) olarak sıralanabilir. Paralel metinler terim bilgisi konusunda bana yol gösterici nitelikte oldu. Metindeki terimleri araştırmadan ve terim tablosu oluşturmadan verimli bir çeviri yapacağımı düşünmediğimden terim tablosu oluşturdum ve saptadığım terimleri alanına göre terim anlamları bulabileceğim çevrimiçi kaynaklar ve bulduğum Türkçe, Fransızca ve yoğunlukla İngilizce paralel metin taramalarından aldığım bilgilerle tanımladım. Dilimize İngilizce olarak geçmiş Fransızca -özellikle paralel metinlerde de İngilizce olarak kullanılmış- terimleri yine paralel metinler ışığında terimin kaynak dilinde de erek metinde kullanılabildiğini düşündüm ancak bazı terimler için çevirmen notuyla da açıklayabileceğim şekilde Türkçeleştirme yolunu tercih ettim. Bu noktada tek bir kelime bütünüyle açıllanmayacak terimleri teknolojinin anadili olan İngilizce versiyonuyla yer vermeyi tercih ettim; bunları da çevirmen notlarıyla destekledim. Çevirimi oluştururken, çevrimiçi kaynaklardan birisi olan Google Translate'den, genel anlamda "cümlenin neyi anlatmak istediğini, kelimelerin ilk anlamları mı diğer anlamları mı baz alınmalı” gibi konularda yardım aldım. Bir yapay zekâ girişimi olduğunu düşündüğüm Google Çevirinin, - metnin içeriğinde yapay zekadan bahsedildiği gibi yeterince gelişmemiş olduğunu - insan zekasının yerini alamayacağını düșündüm bu sebeple de oluşturulan sonuç üzerinde düzenlemelerim oldukça fazlaydı, özellikle belirlediğim terimlerle ilgili olumlu

Adres

RumeliDE Dil ve Edebiyat Araşttrmaları Dergisi Osmanağa Mahallesi, Mürver Çiçeği Sokak, No:14/8 Kadıköy - İSTANBUL / TÜRKIYE 34714 e-posta: editor@rumelide.com tel: +90 $5057958124,+902167730616$

\section{Address}

RumeliDE Journal of Language and Literature Studies

Osmanağa Mahallesi, Mürver Çiçeği Sokak, No:14/8

Kadıköy - ISTANBUL / TURKEY 34714

e-mail: editor@rumelide.com,

phone: +90 505 7958124, +90 2167730616 
sonuca ulaşamadım, alanları çerçevesinde inceleyebildiğim terimlerin isimlerine yönelik kapsamlı bir düzeltme işlemi yaptım. Önceliğim metnin "teknik" yapısını bozmadan anlaşılır bir şekilde Türkçeye çevirmekti. Bu süreci de yukarıda bahsettiğim aşamalar dahilinde, yalnızca dilbilgisi ve kaynak dile değil; genel olarak bilgi ve araştırmaya dayalı gerçekleştirdim.”

\title{
Ek 3.
}

\section{3 numaralı öğrencinin kaleme aldığı çeviri yorum yazısı}

\begin{abstract}
"Çevirisini yapmış olduğum metin "Gig Ekonomisi”ni ele alıyor. Gig ekonomisi, teknolojinin gelişmesiyle birlikte rahat iş saatleri ile insanlara kolay maddi kazanç sağlayan freelance platformların çoğalmasıyla ortaya çıan bir kavram. Metnimizde bu modelin tam olarak ne olduğundan, nasıl işlediğinden ve ne gibi kazançlar sağladığından bahsediliyor. Metnin genel alanı 'ekonomi' ye dayanıyor. Ve ele alabileceğimiz birçok terim mevcut fakat alt alan olarak çok bir çeşitlilik söz konusu değil. Alt alan bazında genel olarak 'teknoloji' alanında terimler yer alıyor. Bu alt alana örnek verecek olursak 'Yapay zekâ' nın metinde yer yer geçtiğini göreceksiniz ya da 'mikroiş' ve 'maliyet' gibi alt alanı 'ekonomi' olan terimleri... Paralel metin kapsamında varış dilinden çok İngilizce yazılmış daha çok metine ulaşmak mümkün. Fakat konuyla ilgili detaylıca bilgi veren Türkçe hazırlanmış metinler de var. Hem konuya daha hâkim olmak için hem de terim araştırması yaparken bu tarz metinlerden çok fazla yararlandığımı söyleyebilirim. Çeviri aşamasında doğru anlam ve kelimeyi yakalamak için kullandığım birkaç online sözlük mevcut ve bunlar doğruluğundan \%95 emin olduğum kaynaklar. Sadece çıan sonucun üzerinde biraz düşünmem ve konuya ilişkin en doğru kelimeyi seçmem gerekiyor. Bu seçimleri de genellikle çok dilli bir araştırmayla elde ediyorum. Onun dışında yer yer otomatik çeviri programlarına ihtiyacım oluyor fakat bu programlar tam olarak doğru sonucu vermiyor ve genelde sadece cümlenin iskeletini çıkarmamda ve genel bir fikir sahibi olmamda yardımcı oluyor. O yüzden çıkan sonuç üzerinde çok fazla oynama ve düzeltme yapmam gerekiyor. Metinde izlediğim çeviri stratejisi genel olarak kelimeleri Türkçe karşılıklarıyla yazmaktı fakat birkaç yerde özellikle İngilizce kelimeleri olduğu gibi bırakmayı seçtim. Çünkü kaynak metindeki bazı yerlerde terimleri kendim oluşturdum ve bilmeyen ya da anlayamayanlar için İngilizce karşılığından çağrışım yapabileceklerini düşündüm. Metnin konusu olan ve çoğu yerde İngilizce olarak yazılmış olan “Gig Economy”yi Türkçeye çevirme gereksinimi duydum. Fakat aynı zamanda Türkçede de dilimize İngilizce olarak yer edinmiş kelimeler var ve metinde bunları aynı şekilde yazmayı tercih ettim (örneğin freelance). Genel ve son olarak metnin anlamından ve konusundan taşmamaya ve metni güzel bir dil ve çeviriyle oluşturmaya gayret ettiğimi söylemeliyim. Bu çeviri çalışması sayesinde kendi adıma bilmediğim çok fazla şey öğrendim. Umarım size de bir şeyler katan bir metin olmuştur."
\end{abstract}

\section{Ek 4.}

\section{4 numaralı öğrencinin kaleme aldığı çeviri yorum yazısı}

"MTF 2141 kodlu Teknik Çeviri 1 dersi kapsamında Esnek Ekonomi (Gig Economy) metniyle ilgili bir teknik çeviri çalışmasıdır. Bu Teknik Çeviride alınan kararlardan bahsetmeden önce kısaca esnek ekonomi hakkında bilgi vermek istiyorum. Esnek Ekonomi (Gig Economy) teknolojinin hızla gelişmesi, insanların özgürce maddi kazanç sağlama isteği ve freelance platformların çoğalmasıyla ortaya çıkan bir kavramdır. Esnek Ekonomi(Gig economy) iş dünyasının yeni kavramı olduğu için bazı kavramlar Türkçe de kesin olarak çevrilmediği veya yeni tanımlanmış bir kavram olduğu için çevirmen olarak bazı terimlerde kararlar almak durumunda kaldım. İlk kısımda anlatmış olduğum gibi bu teknik metin dijital ekonomi ve finans çatı alanlarından oluşmaktadır. Bu durumda alana dijital ekonomi ya da finans olarak alabilirken, alt alanları ise: teknoloji, yapay zekâ gibi örnekler ile çeşitlendirilebilir. Örneğin: "IA", "base de donnée" terimlerini bu alt alanlara örnek olarak verebiliriz. Her ne kadar kısa bir metin olsa da bu çeviride terim çalışması yapmadan hiçbir şekilde çalışamazdım ve bu yüzden terim tablosu oluşturdum ve bununla birlikte paralel metin çalışmamı gerçekleştirdim. Bu çalışma sayesinde terimlerin daha önce çevrilip çevirmediği konusunda tutarlılık yakaladım. Paralel metin araştırmalarımda hem Türkçe hem İngilizce birçok kaynağa ulaştım. Fakat ilk başta da dediğim gibi Esnek Ekonomi hakkında Türkçe de ulaşamadığım terimler oldu, bu terimlerde kelimenin Fransızcasını ekleyip çevirmen notu ile destekledim. Bu kararın daha doğru olacağını düşündüm çünkü iş dünyasının'da evrensel dili maalesef İngilizce. Ama bazı terimleri ise yerlileştirme yapmaya doğru gittim.. Ek olarak, çeviri sürecimde, "yandex çeviri” veya "google translate" otomatik çeviri programlarını önerilerine baktım. Sonuç olarak çevirmenin yaratıcılığı, kültürel entonasyonlarını bile düşünürken otomatik çevirilerin hiçbir zaman yaratıcı

RumeliDE Dil ve Edebiyat Arașttrmaları Dergisi Osmanağa Mahallesi, Mürver Ciceği Sokak, No:14/8 Kadıköy - ISTANBUL / TÜRKIYE 34714 e-posta: editor@rumelide.com tel: +90 $5057958124,+902167730616$

\section{Address}

RumeliDE Journal of Language and Literature Studies

Osmană̆a Mahallesi, Mürver Çiçeği Sokak, No:14/8

Kadıköy - ISTANBUL / TURKEY 34714

e-mail: editor@rumelide.com,

phone: +90 5057958124, +90 2167730616 
olmayacağı gibi aynı kaynak metin'deki aynı hissiyatı vermeyeceğini düşünmekteyim. Bu metin her ne kadar teknik bir metin olmasına rağmen çevirmen birçok karar almak durumundadır. Ayrıca bu kararlar anadilim olan Türkçeye yeni kavramlar ekliyorken mantıklı kararlar olmalıdır.. Herhangi bir alana yerel bir terim katmak aslında bir buluştur. Bir buluş ise bilimdir."

\section{Ek 5.}

\section{5 numaralı öğrencinin kaleme aldığı çeviri yorum yazısı}

"Metinde ele alınan konu internetten bilgisayar başında oturarak yapılabilen günlük, saatlik işler ve günlük veya saatlik çalışlarak gerçek anlamda beden kullanılarak yapılan işler ve bu işleri yaptıran sistemlerin amaçları ve olabilecek sonuçları doğrultusundaydı. Metnin ana alanı Ekonomiydi. Bu alan doğrultusunda alt alanlar ise yeni iş modeli olan Esnek ekonomi ve Teknolojiydi. Bu altalanlara örnek olarak Esnek ekonomi için "Clickworker", "Freelancer" ve "Mikro-iş" terimleri örnek verilebilir. Teknoloji içinse aşağıda bahsedilen birçok şirket ismi ve çalışma şekli terim olarak örnek verilebilir. Çevirime başlamadan önce bu metni okuyup konu hakkında araştırmalar yaptım. Yaptığım araştırmalar sonucunda bu metnin de İngilizcenin etkisi altında kaldığını gördüm ve bazı terimlerin Türkçe karşılığını araştırma sonuçlarımda yine İngilizce halinde buldum. Çeviri sırasında birçok kez tırnak içindeki anlatımı vermek için eklemelerde bulundum. "Clickworker" terimi hem bu bahsedilen çalışma sitelerinden biriyken hem de bu şekilde çalışılan kişilere verilen ad olduğu için bu terimi kullanmayı seçtim. Dilimize geçmiş bazı terimleri olduğu gibi bıraktım çünkü tek bir kelimeyi 3-4 kelimede açıklamak veya okurların bu konuyu benim gibi araştırmak istediklerinde yararlı kaynaklara ulaşamamasını istemedim. Sadece başlıkta "Geçici Ufak Tefek İşler" olarak aldığım terimimin Fransızcası "des petits boulots" İngilizcesi ise "odds-jobs" idi. Yeni bir terim katmak için biraz fazla uzun olabileceğinden insanların "nedir bu geçici ufak tefek işler?” diye düşünmesini ve bu konuyu irdelemelerini istedim. Yani orijinal metinde ve bağlamda var olan terimi okurlara bu şekilde götürmek ve bu şekilde bir köprü kurmak istedim. Çeviri motorlarını kullandığım zaman genelde sadece kelimelere bakıyorum veya nasıl bir yol izlemiş diye kontrol ediyorum. Bazen çeviri motorlarını İngilizceden Fransızcaya veya tam tersi şekilde kullanıyorum. Bunun dışında genellikle larousse gibi siteleri kullanıyorum ve en çok yararlandığım fakat hala Türkçe dilinin beta aşamasında olan Reverso sitesi var. Bu siteyi bağlamlarda nasıl kullanılmış diye kontrol etmek için kullanabiliyorum fakat hem beta aşamasında hem de dijital bir yazılım olduğu için yine kendi görüşüm ve araştırmalarım doğrultusunda bir terime ve kelimeye karşılık buluyor ve o şekilde çevirimi tamamlıorum.”

\begin{tabular}{r|l} 
Adres & Address \\
RumeliDE Dil ve Edebiyat Araştırmaları Dergisi & RumeliDE Journal of Language and Literature Studies \\
Osmanağa Mahallesi, Mürver Çiçeği Sokak, No:14/8 & Osmanağa Mahallesi, Mürver Çiçeği Sokak, No:14/8 \\
Kadıköy - İSTANBUL / TÜRKIYYE 34714 & Kadıöy - ISTANBUL / TURKEY 34714 \\
e-posta: editor@rumelide.com & e-mail: editor@rumelide.com, \\
phone: +90 505 7958124, +90 2167730616
\end{tabular}

